\title{
Chitosan as a Growth Promoter and Enhance Survival Rate in an in vitro Culture of Banana (Musa spp.) Cultivar 'Bantala'
}

\author{
Laxman Kandha1, Rahul Kumar², Birendra Kumar Bindhani ${ }^{1}$
}

10.18805/IJARe.A-5747

\begin{abstract}
Background: Banana (Musa spp.) is one of the most consumable fruits and cultivated around the globe. It contains high nutritional value as well as the high demand of the market. The microbes are the main problem for the propagation of banana plants in tissue culture. Chitosan is one of the best substances for the eradication of contamination and also growth stimulators of banana plants. This study is based on the micro-propagation of the bantala variety of Musa species and free from microbe infection.

Methods: The rhizome and sucker as explants of Musa cv. Bantala. The different combination concentrations of 6-Benzylaminopurine (BAP), indole-3-acetic acid (IAA) and chitosan (CS) were tried in Murashige and Skoog medium for in vitro response of plants, shoot initiation and shoot proliferation. The formation of rooting was used as the half-strength Murashige and Skoog (MS) medium with indole-3-butyric acid (IBA) and chitosan (CS).

Result: The best response, shoot initiation and shoot proliferation were observed at 6 -Benzylaminopurine $(5.0 \mathrm{mg} / \mathrm{L})+\mathrm{indole}-3$-acetic acid $(0.5 \mathrm{mg} / \mathrm{L})+$ chitosan $(25 \mathrm{mg} / \mathrm{L})$ and 6 -Benzylaminopurine $(4.0 \mathrm{mg} / \mathrm{L})+$ indole-3-acetic acid $(0.5 \mathrm{mg} / \mathrm{L})+$ chatoyant $(25 \mathrm{mg} / \mathrm{L})$ in both of rhizome and sucker respectively. The maximum root formations were observed in the medium containing half-strength Murashige and Skoog medium+1.0 mg/L indole-3-butyric acid $+25 \mathrm{mg} / \mathrm{L}$ chitosan in the rhizome and $0.8 \mathrm{mg} / \mathrm{L}$ indole-3-butyric acid+25 mg/L chitosan in the sucker. The successful survival rate of sucker and rhizome under the acclimatization condition was recorded as $90 \%$ and $88 \%$ compared with control as $66 \%$ and $63 \%$ respectively. This standardized protocol might be useful for the mass production of bantala variety as well as other cultivars of banana plants.
\end{abstract}

Key words: Bantala, BAP, Chitosan, IBA, IAA, Rhizome, Sucker.

\section{INTRODUCTION}

Banana (Musa spp.) is the herbaceous monocotyledonous plant and it belongs to the Musaceae family. It's mostly cultivation in tropical and subtropical regions worldwide and in India, Kerala, Karnataka, Gujarat, Orissa, Bihar, Eastern Uttar Pradesh, West Bengal, Assam, North Eastern states are the major producers Saravanapandeeswari and Vanitha (2018). The banana developed more than one hundred twenty nations covering just about ten million hectares with 95 million tons generation of one year. On the basis of production of food crops, the rice is at $1^{\text {st }}$, the wheat at $2^{\text {nd }}$, the maize at $3^{\text {rd }}$ rank Rout et al. (2000) and followed by banana remains at the $4^{\text {th }}$ rank Saravanapandeeswari and Vanitha (2018). Initially, banana generation started from Southeast Asia and after that production of this species gradually spread whole over India Chaurasia et al. (2017). Above '970' indigenous banana were collected from India and kept in the National Research Centre on Banana (NRCB), Tiruchirappalli, Tamil Nadu, India. China acquires the top position in fruit producer but the second position in India around the world but in the case of banana, India top most banana production than China. The total annual production of fruits has been estimated to be 88.97 metric tons (MT) from an area of 6.38 Million ha (Rathod and Mishra, 2018). To demonstrated and found the no somaclonal variation as well as free from viral contamination of the explants from both sucker and rhizome of banana explants Kacar et al. (2012). The sucker was used for the propagation of banana plantlets through vegetative methods but its slow
1Plant Tissue Culture Lab, School of Biotechnology, Kalinga Institute of Industrial Technology (KIIT), Deemed to be University, Bhubaneswar-751 024, Odisha, India.

${ }^{2}$ Amity Institute of Biotechnology, Amity University Jharkhand, Ranchi-834 001, Jharkhand, India.

Corresponding Author: Birendra Kumar Bindhani, Rahul Kumar, Plant Tissue Culture Lab, School of Biotechnology, Kalinga Institute of Industrial Technology (KIIT), Deemed to be University, Bhubaneswar-751 024, Odisha, India; Amity Institute of Biotechnology, Amity University Jharkhand, Ranchi-834 001, Jharkhand, India. Email: drbindhani@gmail.com; rhlkmr104@gmail.com.

How to cite this article: Kandha, L., Kumar, R. and Bindhani, B.K. (2022). Chitosan as a Growth Promoter and Enhance Survival Rate in an in vitro Culture of Banana (Musa spp.) Cultivar 'Bantala'. Indian Journal of Agricultural Research. DOI: 10.18805/ IJARe.A-5747.

Submitted: 30-01-2021 Accepted: 02-12-2021 Online: 17-01-2022

production, time-consuming as well as cause diseases and very poor preservation (Hussein, 2012). The microrhizome based clonal propagation is already reported in Curcuma caesia Roxb. Sarma et al. (2021).The production of good quality banana crops affects viral diseases through nonprofessional cultivation Wambugu et al. (2008). An invitro culture was better than a conventional method for the propagation of banana plants because of genetic uniformity, a short period, high plantlet production, disease-free and round the year (Ortiz and Vuylsteke, 1996). The propagation 
of banana plants through tissue culture techniques $30 \%$ higher than the conventional method Pradeep et al. (1992). A single plant or a small piece of tissue (explants) can be produced a large number of uniform disease-free plants through in vitro culture method Borah et al. (2019). Chitosans are linear polysaccharides. It's made from chitin shells of shrimp, crabs and other crustaceans with an alkaline substance and is also found in both fungal and insect cell walls Walker-Simmons et al. (1983). It's also the antifungal agent against plant disease resistance and nontoxic effect on the environment (Vander et al. 1998; Benhamou et al. 1994; El-Ghaouth et al. 1994, Cassells et al. 1999; Roby et al. 1987 and Tiuterev et al. 1996). Chitosan has so many properties like growth stimulator, antimicrobial properties, plant disease resistance, biodegradability, biocompatible for the environment, etc Uthairatanakij et al. (2007). This study is based on the effect of various phytohormones and chitosan with MS medium for the propagation of bantala variety of banana plants by invitro culture and prevents fungal and bacterial infections.

\section{MATERIALS AND METHODS Explants}

The investigation was carried out from 2019-2020, in the department of plant tissue culture (PTC), KIIT School of Biotechnology, Bhubaneswar and Odisha.

Samples were collected from the Orissa University of Agriculture and Technology (OUAT), Bhubaneswar, Odisha. The rhizome and sucker as explants of banana cv. Bantala were selected. The rhizome and sucker were washed thoroughly under running tap water for two hours. The plant materials were dipped into $1 \%$ laboline for fifteen to twenty min. The explants were cleaned thoroughly with sterilized $\mathrm{H}_{2} \mathrm{O}$ and exposed to UV in laminar airflow for fifteen minutes. The explants were dipped in $70 \%$ ethyl alcohol for 60 seconds. Then immediately transferred into sterile glass materials and pour $0.1 \%$ mercuric chloride $\left(\mathrm{HgCl}_{2}\right)$ for ten to fifteen minutes with frequent shaking. The materials were washed thoroughly with sterile distilled water three to four times. Then finally, the explants were dried on sterile filter papers and cut into small in cube size of $0.5 \mathrm{~cm}$ and ready for inoculation on MS medium.

\section{Culture condition}

The plant's growth and development in various stages such as the response of plants, shoot initiation, shoot multiplication and rooting used the full-strength and halfstrength MS (Murashige and Skoog, 1962) media (HiMedia, PT101) with plant growth regulators (PGRs) and Chitosan. CleriGarTM (Himedia, PCT0902) was added at a range of $0.35 \%-0.5 \%(\mathrm{w} / \mathrm{v})$ as gelling agents. MS medium was added by various concentrations of plant growth regulators. The prepared media has adjusted the $\mathrm{pH} 5.8$ by $0.1 \mathrm{~N} \mathrm{NaOH}$ or $\mathrm{HCL}$ and sterilized in autoclaves at $121^{\circ} \mathrm{C}$ and $15 \mathrm{psi}$ for twenty minutes. Then the prepared explants were inoculation in MS medium. All cultures were carried out into the culture room. The cultures were incubated at $25 \pm 2{ }^{\circ} \mathrm{C}$ and $16 / 8 \mathrm{hrs}$ photoperiod using cool-white fluorescent lights $(50 \mu \mathrm{moL}$ $\mathrm{m}^{-2} \mathrm{~s}^{-1}$ ) and the culture room maintained $60 \%$ of relative humidity.

\section{Chitosan solution preparation}

The preparation of a stock solution $(100 \mathrm{mg} / \mathrm{L})$ of chitosan powder (Himedia, TC242) was dissolved by $4 \mathrm{M} \mathrm{HCL}$. The adjustment of $\mathrm{pH}$ value before the slurry was added into the media.

\section{Phytohormones and Chitosan trial concentrations range}

BAP: $0.0,1.0,2.0,3.0,4.0,5.0,6.0,7.0,8.0$ and $9.0 \mathrm{mg} / \mathrm{L}$ IAA: $0.0,0.1,0.2,0.3,0.4,0.5,0.6,0.7,0.8$ and $0.9 \mathrm{mg} / \mathrm{L}$ IBA:0.0, 0.2, 0.4, 0.6, 0.8, 1.0,1.2, 1.4, 1.6 and $1.8 \mathrm{mg} / \mathrm{L}$ Chitosan : $0.0,5.0,10,15,20,25,30,35,40$ and $45 \mathrm{mg} / \mathrm{L}$

\section{The response of rhizome and sucker explants}

There were used different combination concentrations of $B A P, I A A$, chitosan and full-strength MS medium in rhizome and sucker explants. Both explants were tried 100 combination concentrations separately for the response of explants. To observed the data based on the visual gradation i.e. inoculated explants initially swelling and after greenish color as considered but black in color plants discarded. The data scored after one week from inoculation.

\section{The response, Shoot initiation, Shoot proliferation and} rooting

The selected best 10 numbers of concentrations were used for the experiments. To follow the response, shoot initiation and proliferation medium (full-strength MS with BAP, IAA and chitosan) after completed the response stage of explants in both rhizome and sucker. To removed the unwanted shoot parts from the cut of initiated explants and transferred the explants to a multiplication medium (full-strength MS with BAP, IAA and chitosan). The response of explants was observed and recorded based on the swelling, greenish color of the explants after one week from the inoculation. Similarly, shoot initiation and proliferation were recorded based on the size of the explants after two weeks and three weeks DPI (days post-inoculation) respectively. The multiplied explants were separated thoroughly and transferred to rooting medium i.e. half-strength MS, IBA and chitosan. The roots data scored based on the size of the roots. All roots data documentation after one week and two weeks from the inoculation.

The well-developed roots were washed thoroughly under the running tap water. The fungicide of Bavastin (1.5$2 \mathrm{~g} / \mathrm{L}$ ) was used for treating all rooted plantlets for twenty minutes. The roots plants were shifted into polythene bags which contain autoclaved sand, soil rite and cow excrete i.e. all were in one ratio and kept for 5-8 days with sprinkling water in room condition. Then all packing plantlets were carried out to the greenhouse. Finally, rooted plants were transferred to the field condition after one month. 


\section{Data analysis}

The experiments were repeated three times and each treatment was ten explants. The data recorded on the response of explants, shoot initiation, shoot proliferation and formation of the roots in both explants. Characteristics of the explants were analyzed by ANOVA and means were compared using Duncan's multiple range test (Gomez and Gomez, 1984) at a $5 \%$ significance level $(p \leq 0.05)$.

\section{RESULTS AND DISCUSSION}

The optimum ten different concentrations were selected out of 100 different concentrations for the response of both rhizome and sucker explants (Tables 1 and 2).

The maximum responses, shoot initiation and shoot proliferation were observed when a concentration as $\mathrm{MS}+5$ $\mathrm{mg} / \mathrm{L} \mathrm{BAP}+0.5 \mathrm{mg} / \mathrm{L} \mathrm{IAA}+25 \mathrm{mg} / \mathrm{L}$ chitosan in the rhizome and $\mathrm{MS}+4 \mathrm{mg} / \mathrm{L} \mathrm{BAP}+0.5 \mathrm{mg} / \mathrm{L} \mathrm{IAA}+25 \mathrm{mg} / \mathrm{L}$ chitosan in the sucker explants (Table 3 and Graph 1). The different developmental stages of rhizome and sucker plants were observed after one, two and three weeks respectively from the day post-inoculation (Fig 1 and Fig 2). According to the increases of 6-Benzylaminopurine concentration up-to 5.0 $\mathrm{mg} / \mathrm{L}$ similarly increases of shoot proliferation and thereafter decreased but in both explants, as $0.5 \mathrm{mg} / \mathrm{L}$ IAA concentration remained constant. Previous researchers already reported that the percentageof shoot regeneration high with the increases of 6-Benzylaminopurine concentration up to $5.0 \mathrm{mg} / \mathrm{l}$ and thereafter declined (Sidha et al. 2007; Perez-Hernandez and Rosell-Garcia, 2008; Darvari et al. 2010; Sultan et al. 2011). Likewise, many researchers were depicted that number of shoot initiation and multiplication highest (Deo and Pradhan, 2017) where the concentration at $4 \mathrm{mg} / \mathrm{L}$ BAP along with $0.5 \mathrm{mg} / \mathrm{L}$ IAA. Muhammad et al. (2007) was found the identical result by 4 $\mathrm{mg} / \mathrm{L} \mathrm{BAP}+1 \mathrm{mg} / \mathrm{L}$ IAA concentration. Both Ahmed et al. (2014) and Habiba et al. (2002) were observed at $4 \mathrm{mg} / \mathrm{L}$ BAP+2 $\mathrm{mg} / \mathrm{L}$ IAA concentration shown the highest multiple shoot formations. The chitosan has a growth promoter not only in the orchid tissue culture of the plants but also in the in vitro culture of the several species of the plants (Nge et al. 2006; Ohta et al. 1999; AitBarka et al. 2004 and Sopalun et al. 2010).

Table 1: Response of rhizome explants of banana (Musa spp.) cultivar 'Bantala' in Murashige and Skoog (MS) medium supplemented with different concentrations of 6-Benzylamino purine (BAP), Indole-3-acetic acid (IAA) and chitosan (CS) at 7 days postinoculation.

\begin{tabular}{|c|c|c|c|c|c|c|c|c|c|c|c|}
\hline \multirow{2}{*}{$\mathrm{IAA}(\mathrm{mg} / \mathrm{L})$} & \multicolumn{10}{|c|}{ BAP (mg/L) } & \multirow{2}{*}{$\begin{array}{r}\text { Chitosan } \\
\text { (mg/L). }\end{array}$} \\
\hline & 0.0 & 1.0 & 2.0 & 3.0 & 4.0 & 5.0 & 6.0 & 7.0 & 8.0 & 9.0 & \\
\hline 0.0 & - & - & - & - & - & - & - & - & - & - & 0.0 \\
\hline 0.1 & - & - & - & - & - & - & - & - & - & - & 5.0 \\
\hline 0.2 & - & - & - & - & + & + & + & - & - & + & 10.0 \\
\hline 0.3 & - & - & + & + & ++ & +++ & ++ & + & ++ & - & 15.0 \\
\hline 0.4 & - & - & - & ++ & ++ & +++ & +++ & +++ & ++ & - & 20.0 \\
\hline 0.5 & + & + & ++ & ++ & +++ & ++++ & +++ & +++ & + & + & 25.0 \\
\hline 0.6 & + & - & + & ++ & +++ & +++ & ++ & ++ & + & + & 30.0 \\
\hline 0.7 & + & ++ & + & ++ & ++ & ++ & + & + & + & + & 35.0 \\
\hline 0.8 & + & ++ & - & + & - & ++ & ++ & - & - & - & 40.0 \\
\hline 0.9 & - & - & - & - & - & - & + & - & - & - & 45.0 \\
\hline
\end{tabular}

Visual gradation: No response '-', Very poor response '+', Poor response '++', Good response '+++', Very good response '++++'.

Table 2: Responseof sucker explants of banana (Musa spp.) cultivar 'Bantala' in Murashige and Skoog (MS) medium supplemented with different concentrations of 6-Benzylamino purine (BAP), Indole-3-acetic acid (IAA) and chitosan (CS) at 7 days post-inoculation.

\begin{tabular}{|c|c|c|c|c|c|c|c|c|c|c|c|}
\hline \multirow{2}{*}{ IAA (mg/L) } & \multicolumn{10}{|c|}{ BAP (mg/L) } & \multirow{2}{*}{$\begin{array}{r}\text { Chitosar } \\
(\mathrm{mg} / \mathrm{L})\end{array}$} \\
\hline & 0.0 & 1.0 & 2.0 & 3.0 & 4.0 & 5.0 & 6.0 & 7.0 & 8.0 & 9.0 & \\
\hline 0.0 & - & - & - & - & - & - & - & - & - & - & 0.0 \\
\hline 0.1 & - & - & - & - & - & - & - & - & - & - & 5.0 \\
\hline 0.2 & - & - & - & - & + & ++ & + & - & - & + & 10.0 \\
\hline 0.3 & - & - & + & + & - & + & ++ & ++ & + & - & 15.0 \\
\hline 0.4 & - & - & - & ++ & ++ & +++ & +++ & +++ & ++ & - & 20.0 \\
\hline 0.5 & + & + & ++ & +++ & ++++ & +++ & +++ & +++ & + & + & 25.0 \\
\hline 0.6 & + & + & + & ++ & +++ & +++ & ++ & ++ & + & + & 30.0 \\
\hline 0.7 & + & ++ & + & + & + & + & ++ & + & ++ & + & 35.0 \\
\hline 0.8 & + & + & - & + & + & ++ & + & - & - & - & 40.0 \\
\hline 0.9 & - & - & - & - & - & - & + & - & - & - & 45.0 \\
\hline
\end{tabular}

Visual gradation: No response '-', Very poor response '+', Poor response '++', Good response '+++', Very good response '++++'. 
Table 3: Response of rhizome explants of banana (Musa spp.) cultivar 'Bantala' at 7 days post-inoculation (at 7 DPI)), shoot initiation (at $14 \mathrm{DPI}$ ) and shoot proliferation (at $21 \mathrm{DPI}$ ) in Murashige and Skoog (MS) medium supplemented with different concentrations of 6-Benzylamino purine (BAP), Indole-3-acetic acid (IAA) and chitosan (CS).

\begin{tabular}{|c|c|c|c|c|}
\hline Type of explants & $\begin{array}{l}\text { Treatments } \\
\text { (BAP, IAA, and CS in mg/L) }\end{array}$ & $\begin{array}{l}\text { Response of explants } \ddagger \\
\text { Mean } \pm \text { S.D. }\end{array}$ & $\begin{array}{l}\text { Shoot initiation } \S \\
\text { Mean } \pm \text { S.D. }\end{array}$ & $\begin{array}{l}\text { Shoot proliferation } \mathbb{1} \\
\text { Mean } \pm \text { S.D. }\end{array}$ \\
\hline \multirow[t]{11}{*}{ Rhizome } & MS Only (control) & $1.33 \pm 0.57^{b}$ & $3.33 \pm 0.57^{b}$ & $2.33 \pm 0.65^{b}$ \\
\hline & $\mathrm{MS}+5.0 \mathrm{BAP}+0.3 \mathrm{IAA}+15 \mathrm{CS}$ & $1.66 \pm 0.57^{b}$ & $3.66 \pm 0.58^{b}$ & $2.66 \pm 0.57^{b}$ \\
\hline & $\mathrm{MS}+5.0 \mathrm{BAP}+0.4 \mathrm{IAA}+20 \mathrm{CS}$ & $1.43 \pm 0.57^{b}$ & $3.86 \pm 0.57^{b}$ & $2.34 \pm 0.63^{b}$ \\
\hline & $\mathrm{MS}+6.0 \mathrm{BAP}+0.4 \mathrm{IAA}+20 \mathrm{CS}$ & $1.73 \pm 0.57^{\mathrm{ab}}$ & $3.33 \pm 0.53^{b}$ & $2.53 \pm 0.82^{b}$ \\
\hline & $\mathrm{MS}+7.0 \mathrm{BAP}+0.4 \mathrm{IAA}+25 \mathrm{CS}$ & $1.83 \pm 0.57^{\mathrm{ab}}$ & $4.03 \pm 0.57^{\mathrm{a}}$ & $2.66 \pm 0.67^{b}$ \\
\hline & $\mathrm{MS}+4.0 \mathrm{BAP}+0.5 \mathrm{IAA}+25 \mathrm{CS}$ & $2.33 \pm 0.37^{a}$ & $3.66 \pm 0.35^{\mathrm{b}}$ & $3.43 \pm 0.51^{\mathrm{a}}$ \\
\hline & $\mathrm{MS}+5.0 \mathrm{BAP}+0.5 \mathrm{IAA}+25 \mathrm{CS}$ & $2.66 \pm 0.57^{a}$ & $4.33 \pm 0.57^{a}$ & $3.33 \pm 0.52^{\mathrm{a}}$ \\
\hline & $\mathrm{MS}+6.0 \mathrm{BAP}+0.5 \mathrm{IAA}+25 \mathrm{CS}$ & $1.66 \pm 0.57^{b}$ & $4.33 \pm 1.05^{\mathrm{a}}$ & $2.66 \pm 1.02^{\mathrm{b}}$ \\
\hline & $\mathrm{MS}+7.0 \mathrm{BAP}+0.5 \mathrm{IAA}+25 \mathrm{CS}$ & $2.26 \pm 0.57^{\mathrm{a}}$ & $3.66 \pm 0.57^{b}$ & $1.93 \pm 0.57^{b c}$ \\
\hline & $\mathrm{MS}+4.0 \mathrm{BAP}+0.6 \mathrm{IAA}+30 \mathrm{CS}$ & $2.38 \pm 0.57^{a}$ & $3.46 \pm 1.15^{\mathrm{b}}$ & $2.36 \pm 1.15^{b}$ \\
\hline & $\mathrm{MS}+5.0 \mathrm{BAP}+0.6 \mathrm{IAA}+30 \mathrm{CS}$ & $2.66 \pm 0.57^{a}$ & $4.33 \pm 0.57^{\mathrm{a}}$ & $3.33 \pm 0.57^{a}$ \\
\hline \multirow[t]{11}{*}{ Sucker } & MS only (control) & $1.33 \pm 0.47^{b}$ & $3.33 \pm 0.35^{b}$ & $2.26 \pm 35^{\mathrm{b}}$ \\
\hline & $\mathrm{MS}+5.0 \mathrm{BAP}+0.4 \mathrm{IAA}+20 \mathrm{CS}$ & $1.66 \pm 0.57^{b}$ & $3.36 \pm 0.57^{b}$ & $2.26 \pm 0.57^{\mathrm{b}}$ \\
\hline & $\mathrm{MS}+6.0 \mathrm{BAP}+0.4 \mathrm{IAA}+20 \mathrm{CS}$ & $1.33 \pm 0.57^{\mathrm{b}}$ & $3.26 \pm 0.57^{b}$ & $2.66 \pm 0.85^{b}$ \\
\hline & $\mathrm{MS}+7.0 \mathrm{BAP}+0.4 \mathrm{IAA}+25 \mathrm{CS}$ & $1.83 \pm 0.57^{\mathrm{ab}}$ & $3.93 \pm 0.57^{\mathrm{ab}}$ & $2.33 \pm 1.12^{\mathrm{b}}$ \\
\hline & $\mathrm{MS}+3.0 \mathrm{BAP}+0.5 \mathrm{IAA}+25 \mathrm{CS}$ & $1.33 \pm 0.47^{b}$ & $3.66 \pm 0.67^{b}$ & $2.93 \pm 0.57^{\mathrm{ab}}$ \\
\hline & $\mathrm{MS}+4.0 \mathrm{BAP}+0.5 \mathrm{IAA}+25 \mathrm{CS}$ & $1.93 \pm 0.57^{\mathrm{ab}}$ & $4.66 \pm 1.15^{\mathrm{a}}$ & $3.66 \pm 0.57^{a}$ \\
\hline & $\mathrm{MS}+5.0 \mathrm{BAP}+0.5 \mathrm{IAA}+25 \mathrm{CS}$ & $1.83 \pm 0.57^{\mathrm{ab}}$ & $3.36 \pm 0.57^{b}$ & $2.93 \pm 0.52^{\mathrm{ab}}$ \\
\hline & $\mathrm{MS}+6.0 \mathrm{BAP}+0.5 \mathrm{IAA}+25 \mathrm{CS}$ & $1.66 \pm 0.57^{b}$ & $3.26 \pm 1.15^{\mathrm{b}}$ & $2.66 \pm 1.52^{\mathrm{b}}$ \\
\hline & $\mathrm{MS}+7.0 \mathrm{BAP}+0.5 \mathrm{IAA}+25 \mathrm{CS}$ & $1.33 \pm 0.57^{b}$ & $3.31 \pm 0.57^{\mathrm{b}}$ & $2.33 \pm 0.57^{b}$ \\
\hline & $\mathrm{MS}+4.0 \mathrm{BAP}+0.6 \mathrm{IAA}+30 \mathrm{CS}$ & $1.93 \pm 0.57^{\mathrm{ab}}$ & $4.66 \pm 1.15^{\mathrm{a}}$ & $3.66 \pm 1.15^{\mathrm{a}}$ \\
\hline & $\mathrm{MS}+5.0 \mathrm{BAP}+0.6 \mathrm{IAA}+30 \mathrm{CS}$ & $1.30 \pm 0.57^{\mathrm{b}}$ & $3.20 \pm 0.57^{b}$ & $2.66 \pm 0.57^{\mathrm{b}}$ \\
\hline
\end{tabular}

$\$$ Response of explants considered as swelling and greening of explants. § Explants showing initiation of shoot having more than $3 \mathrm{~mm}$ in length considered. I Explants showing shoot having more than $1 \mathrm{~cm}$ in length considered as proliferated explants. The data scored from 10 cultures per treatment and replicated 3 times. The values of the means within column with same letter in superscript are not significant different $(p \leq 0.05)$ by Duncan's multiple range test.

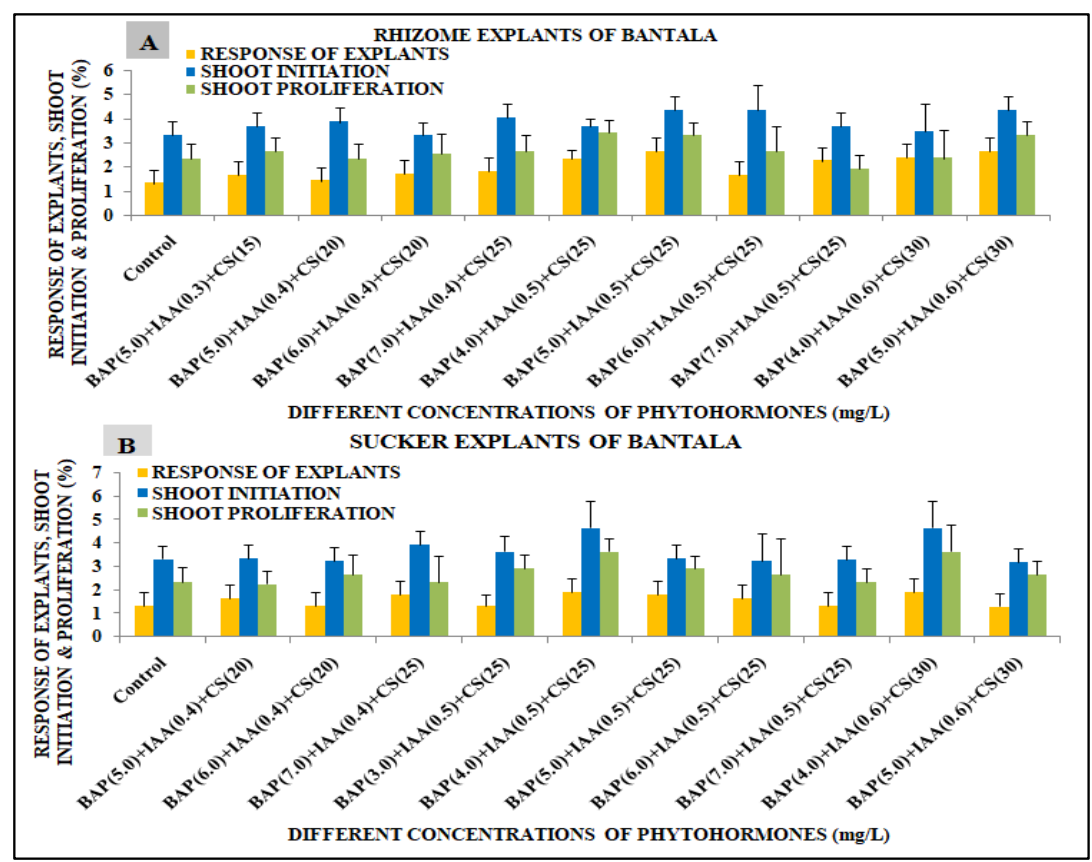

Graph 1: Graph showing response of explants at 7 days post-inoculation (at $7 \mathrm{DPI}$ ), shoot initiation (at $14 \mathrm{DPI}$ ) and shoot proliferation (at $21 \mathrm{DPI}$ ) of rhizome (A) and sucker (B) explants of banana (Musa spp.) cultivar 'Bantala' in Murashige and Skoog (MS) medium supplemented with different concentrations of 6-Benzylamino purine (BAP), Indole-3-acetic acid (IAA) and chitosan (CS). 


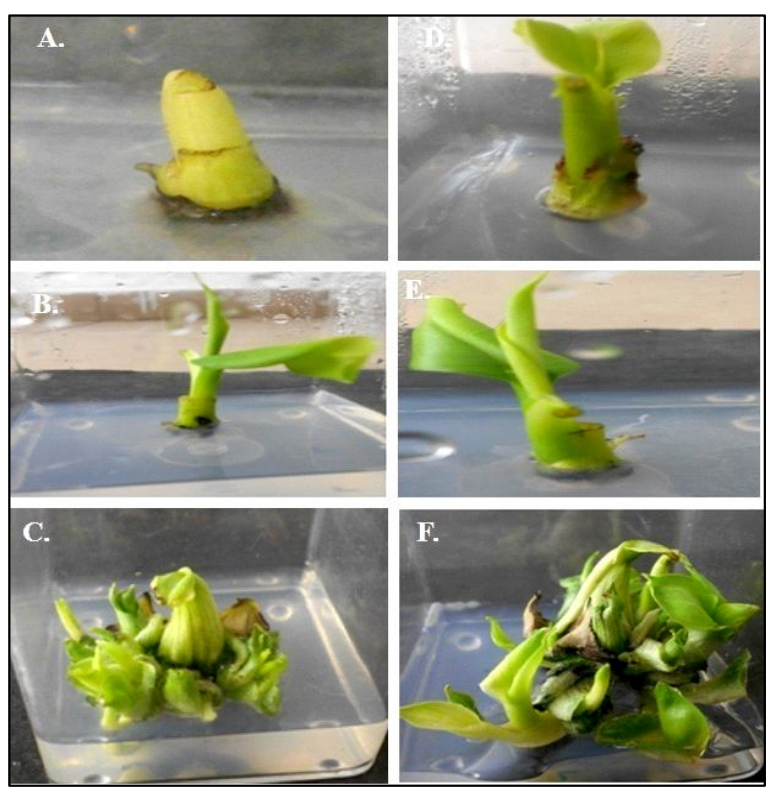

Fig 1: Response of rhizome explants at 7 days post-inoculation (at $7 \mathrm{DPI})$ ), shoot initiation (at $14 \mathrm{DPI}$ ) and proliferation (at 21 DPI) of banana (Musa spp.) cultivar 'Bantala' [Response (Acontrol and D-chitosan with phytohormones), shoot initiation (Bcontrol and E-chitosan with phytohormones) and shoot proliferation (C-control and F-chitosan with phytohormones)].

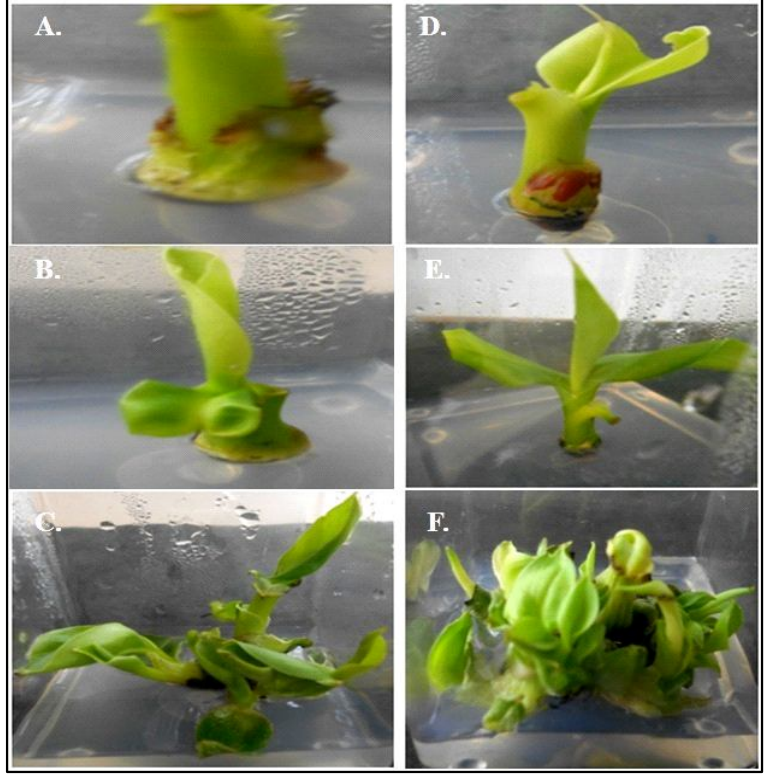

Fig 2: Response of sucker explants at 7 days post-inoculation (at $7 \mathrm{DPI})$ ), shoot initiation (at $14 \mathrm{DPI}$ ) and proliferation (at 21 $\mathrm{DPI}$ ) of banana (Musa spp.) cultivar 'Bantala' [Response (Acontrol and D-chitosan with phytohormones), shoot initiation (Bcontrol and E-chitosan with phytohormones) and shoot proliferation (C-control and F-chitosan with phytohormones)].

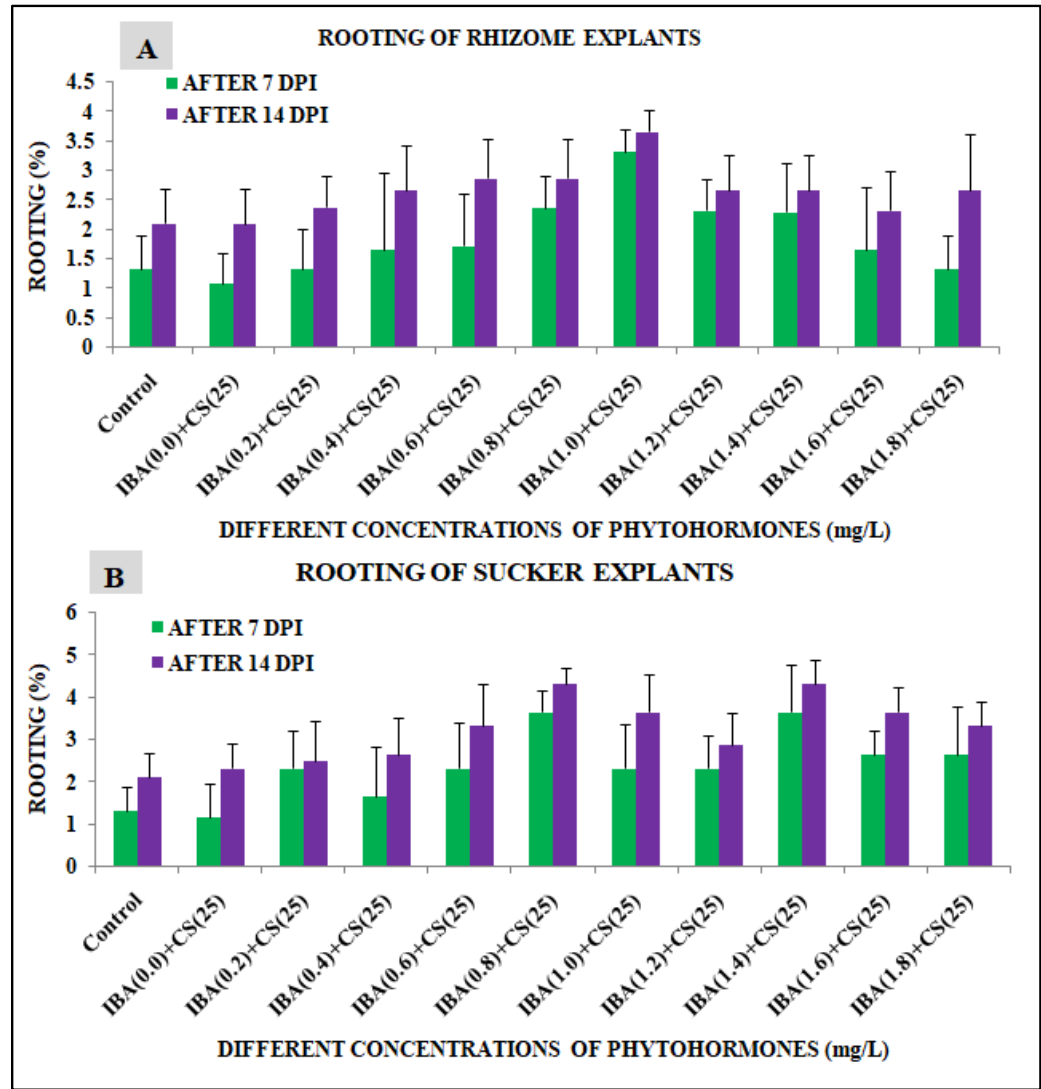

Graph 2: Graph showing rooting at 7 days post-inoculation (at $7 \mathrm{DPI}$ ) and at $14 \mathrm{DPI}$ of rhizome (A) and sucker (B) explants of banana (Musa spp.) cultivar 'Bantala' in half-strength Murashige and Skoog (MS) medium supplemented with different concentrations of Indole-3-butyric acid (IBA) and chitosan (CS). 
After the completed the multiplication stage to follow the rooting stage. Both the explants were used to test the 10 treatments along with positive control. The best concentrations as half-strength $\mathrm{MS}$ medium $+1.0 \mathrm{mg} / \mathrm{L}$ $\mathrm{IBA}+25 \mathrm{mg} / \mathrm{L}$ chitosan in the rhizome and half-strength
$\mathrm{MS}+0.8 \mathrm{mg} / \mathrm{L}$ IBA+25 mg/L chitosan in sucker were observed maximum roots formation (Table 4, Graph 2). There were observed that highest roots induction $(3.33 \pm 0.37)$ and $(3.66 \pm 0.37)$ in rhizome but $(3.66 \pm 0.49)$ and $(4.33 \pm 0.37)$ in sucker respectively (Fig 3 ).

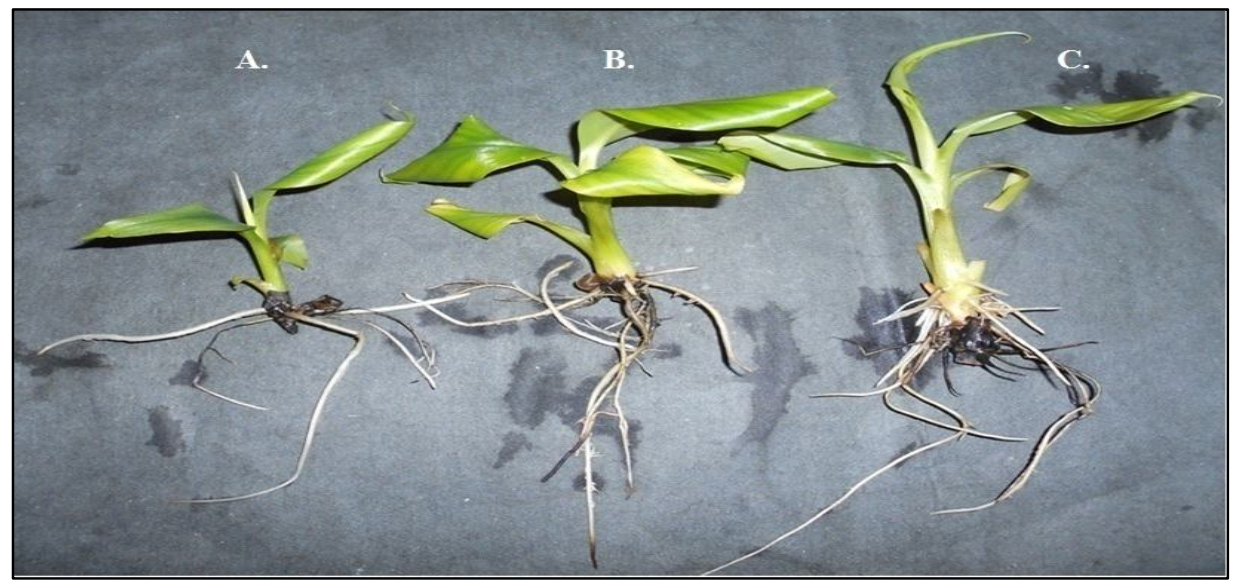

Fig 3: Rooting at 14 days post-inoculation. A-control, B-rhizome (Half-strength Murashige and Skoog medium (MS) $+1.0 \mathrm{mg} / \mathrm{L} \mathrm{Indole-}$ 3-butyric acid (IBA)+25 mg/L chitosan (CS) and C-sucker (1/2MS+0.8 mg/L Indole-3-butyric acid (IBA)+25 mg/Lchitosan (CS).

Table 4: Rooting of rhizome and sucker explants of banana (Musa spp.) cultivar 'Bantala' in half-strength Murashige and Skoog (MS) medium supplemented with different concentrations of Indole-3-butyric acid (IBA) and chitosan (CS), at 7 days post-inoculation (at $7 \mathrm{DPI}$ ) and at $14 \mathrm{DPI}$.

\begin{tabular}{|c|c|c|c|}
\hline Types of explants & $\begin{array}{c}\text { Treatments } \\
\text { (IBA and CS in } \mathrm{mg} / \mathrm{L} \text { ) }\end{array}$ & $\begin{array}{l}\text { After } 7 \text { DPI } \\
\text { Mean } \pm \text { S.D. }\end{array}$ & $\begin{array}{c}\text { After } 14 \text { DPI§ } \\
\text { Mean } \pm \text { S.D. }\end{array}$ \\
\hline \multirow[t]{11}{*}{ Rhizome } & $1 / 2$ MS only (control) & $1.33 \pm 0.57^{c}$ & $2.11 \pm 0.58^{c}$ \\
\hline & $1 / 2 \mathrm{MS}+0.0 \mathrm{IBA}+25 \mathrm{CS}$ & $1.08 \pm 0.53^{c}$ & $2.09 \pm 0.59^{c}$ \\
\hline & $1 / 2 \mathrm{MS}+0.2 \mathrm{IBA}+25 \mathrm{CS}$ & $1.33 \pm 0.67^{c}$ & $2.38 \pm 0.53^{c}$ \\
\hline & $1 / 2 \mathrm{MS}+0.4 \mathrm{IBA}+25 \mathrm{CS}$ & $1.66 \pm 1.30^{c}$ & $2.66 \pm 0.77^{c}$ \\
\hline & $1 / 2 \mathrm{MS}+0.6 \mathrm{IBA}+25 \mathrm{CS}$ & $1.73 \pm 0.87^{\mathrm{bc}}$ & $2.87 \pm 0.67^{b c}$ \\
\hline & $1 / 2 \mathrm{MS}+0.8 \mathrm{IBA}+25 \mathrm{CS}$ & $2.36 \pm 0.55^{b}$ & $2.87 \pm 0.67^{c}$ \\
\hline & $1 / 2 \mathrm{MS}+1.0 \mathrm{IBA}+25 \mathrm{CS}$ & $3.33 \pm 0.37^{a}$ & $3.66 \pm 0.37^{b}$ \\
\hline & $1 / 2 \mathrm{MS}+1.2 \mathrm{IBA}+25 \mathrm{CS}$ & $2.33 \pm 0.52^{b}$ & $2.66 \pm 0.61^{c}$ \\
\hline & $1 / 2 \mathrm{MS}+1.4 \mathrm{IBA}+25 \mathrm{CS}$ & $2.30 \pm 0.82^{b}$ & $2.66 \pm 0.59^{c}$ \\
\hline & $1 / 2 \mathrm{MS}+1.6 \mathrm{IBA}+25 \mathrm{CS}$ & $1.66 \pm 1.05^{\mathrm{c}}$ & $2.33 \pm 0.67^{c}$ \\
\hline & $1 / 2 \mathrm{MS}+1.8 \mathrm{IBA}+25 \mathrm{CS}$ & $1.33 \pm 0.58^{c}$ & $2.66 \pm 0.97^{b c}$ \\
\hline \multirow[t]{11}{*}{ Sucker } & $1 / 2$ MS only (control) & $1.33 \pm 0.53^{c}$ & $2.11 \pm 0.37^{c}$ \\
\hline & $1 / 2 \mathrm{MS}+0.0 \mathrm{IBA}+25 \mathrm{CS}$ & $1.16 \pm 0.82^{c}$ & $2.33 \pm 0.57^{c}$ \\
\hline & $1 / 2 \mathrm{MS}+0.2 \mathrm{IBA}+25 \mathrm{CS}$ & $2.33 \pm 0.88^{b}$ & $2.49 \pm 0.97^{c}$ \\
\hline & $1 / 2 \mathrm{MS}+0.4 \mathrm{IBA}+25 \mathrm{CS}$ & $1.66 \pm 1.18^{c}$ & $2.66 \pm 0.87^{c}$ \\
\hline & $1 / 2 \mathrm{MS}+0.6 \mathrm{IBA}+25 \mathrm{CS}$ & $2.33 \pm 1.08^{b}$ & $3.33 \pm 0.97^{b}$ \\
\hline & $1 / 2 \mathrm{MS}+0.8 \mathrm{IBA}+25 \mathrm{CS}$ & $3.66 \pm 0.49^{a}$ & $4.33 \pm 0.37^{a}$ \\
\hline & $1 / 2 \mathrm{MS}+1.0 \mathrm{IBA}+25 \mathrm{CS}$ & $2.33 \pm 1.03^{b}$ & $3.66 \pm 0.88^{b}$ \\
\hline & $1 / 2 \mathrm{MS}+1.2 \mathrm{IBA}+25 \mathrm{CS}$ & $2.33 \pm 0.77^{\mathrm{b}}$ & $2.88 \pm 0.77^{c}$ \\
\hline & $1 / 2 \mathrm{MS}+1.4 \mathrm{IBA}+25 \mathrm{CS}$ & $3.66 \pm 1.12^{\mathrm{a}}$ & $4.33 \pm 0.57^{a}$ \\
\hline & $1 / 2 \mathrm{MS}+1.6 \mathrm{IBA}+25 \mathrm{CS}$ & $2.66 \pm 0.57^{b}$ & $3.33 \pm 0.57^{b}$ \\
\hline & $1 / 2 \mathrm{MS}+1.8 \mathrm{IBA}+25 \mathrm{CS}$ & $2.66 \pm 1.11^{\mathrm{ab}}$ & $2.66 \pm 0.57^{c}$ \\
\hline
\end{tabular}

\$Plantlets having roots more than size of $1 \mathrm{~cm}$. §Plantlets having roots more than size of $2 \mathrm{~cm}$. The data scored from 10 cultures per treatments and replicated 3 times. The values of the means within column with same letter in superscript are not significant different $(p \leq 0.05)$ by Duncan's multiple range test. 


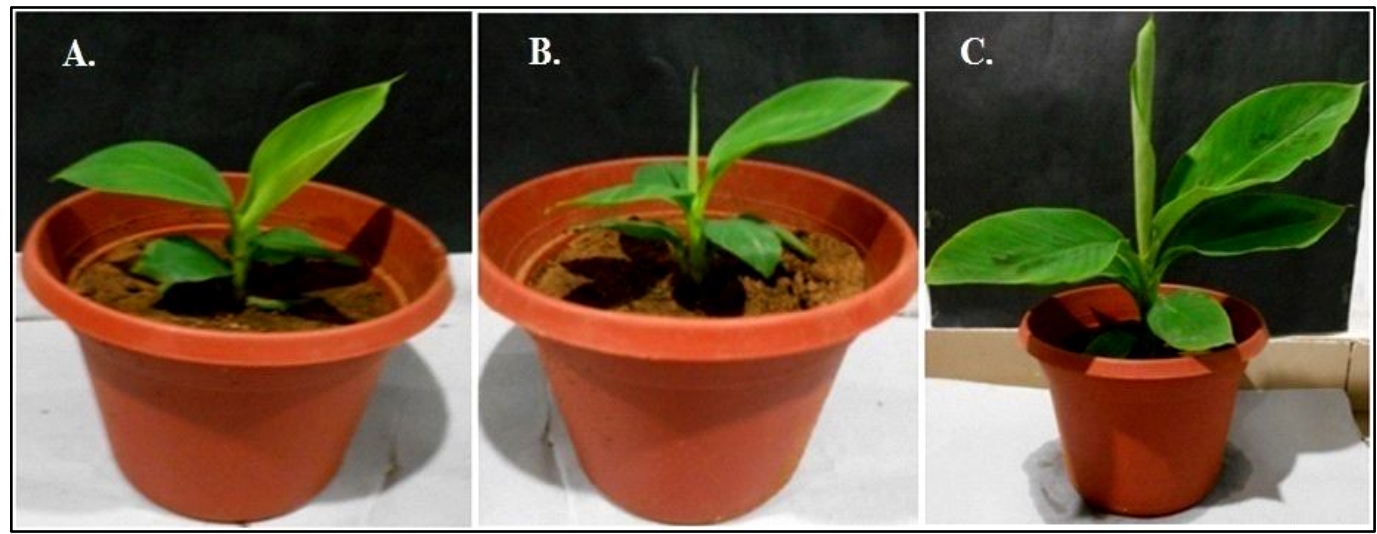

Fig 4: Hardening condition of bantala variety of banana plants A-control, B-rhizome explants treated with chitosan and phytohormones, C-sucker explants treated with chitosan and phytohormones.

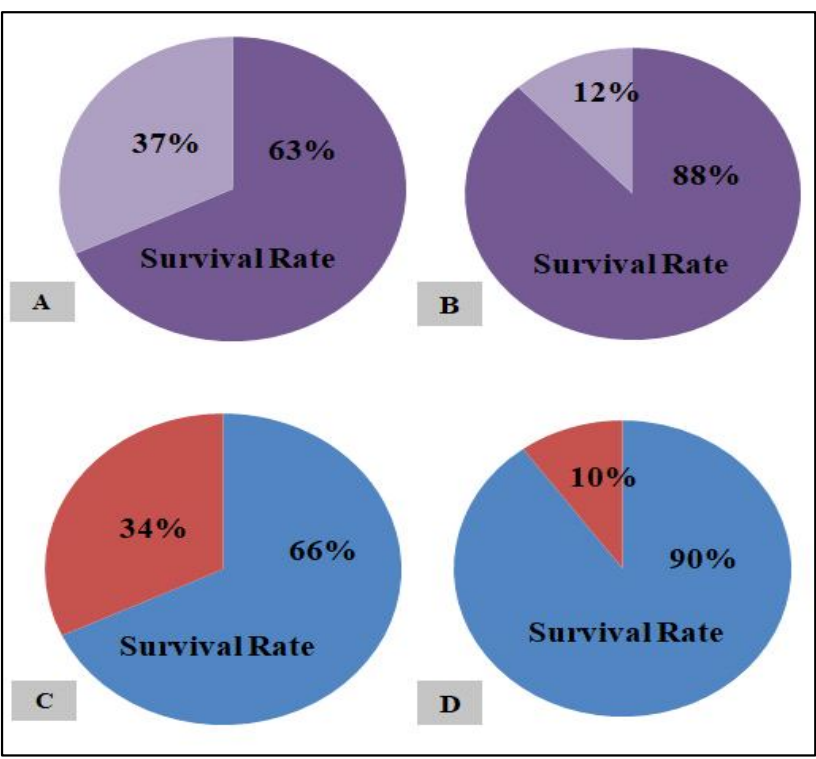

Graph 3: Survival rate of banana plant generated from banana sucker and rhizome under field conditions after hardening. [Acontrol for rhizome explants; B-chitosan with phytohormones of rhizome explants; C-control for sucker explants; andD-chitosan with phytohormonesfor sucker explants].

In field conditions, the survival rates of plantlets were observed $90 \%$ in the sucker and $88 \%$ in rhizome along with control as $66 \%$ and $63 \%$ respectively (Graph 3 ). All invitro regenerated plants successfully developed in hardening conditions (Fig 4).

\section{CONCLUSION}

The Murashige and Skoog medium supplemented with various plant growth regulators (PGRs) and chitosan can better perform for the regeneration of plantlets through in vitro culture of banana plants. However, this technique is financially cheaper and not time consumable. The rhizome and sucker as explants of bantala was the functional unit in the mass propagation of plantlets. So in this way, the demand of the market can be fulfilled. It's likewise different cultivars development and adjusting requirement of the banana to the farmers.

\section{REFERENCES}

Ahmed, S., Sharma, A., Singh, A.K., Wali, V.K. and Kumari, P. (2014). In vitro multiplication banana (Musa sp.) cv. Graindnaine. African Journal of Biotechnology. 13: 2696-2703.

AitBarka, E.A., Eullaffroy, P., Clement, C. and Vernet, G. (2004). Chitosan improves development and protects Vitis vinifera L. against Botrytis cinerea. Plant Cell Report. 22: 608-614.

Benhamou, N., Lafontaine, P.J. and Nicole, M. (1994). Induction of systemic resistance to Fusarium crown and root rot in tomato plants by seed treatment with chitosan. Phytopathology. 84: 1432-1444.

Borah, A.R., Anbumalarmathi, J. and Sharmili, S.A. (2019). In vitro propagation of [Coccinia indica (L.) Voigt]. from internodal segments. Indian Journal of Agricultural Research. 53: 202-207.

Cassells, A.C., Kowalski, B., Fitzgerald, D.M. and Murphy, G.A. (1999). The use of image analysis to study developmental variation in micropropagated potato (Solanum tuberosum L.) plants. Potato Research. 42: 541-548.

Chaurasia, A.K., Patil, H.B., Krishna, B., Subramaniam, V.R., Sane, P.V. and Sane, A.P. (2017). Flowering time in banana (Musa spp.), a day neutral plant, is controlled by at least three Flowering Locus $\mathrm{T}$ homologues. Scientific reports. 7: 5935.

Darvari, F.M., Sariah, M., Puad, M.P. and Maziah, M. (2010). Micropropagation of some Malaysian banana and plantain (Musa sp.) cultivars using male flowers. African Journal of Biotechnology. 9: 2360-2366.

Deo, B. and Pradhan, B. (2017): Effects of plant growth hormones on shoot proliferation of Musa paradisiaca cv. Bantal. International Journal of Plant Sciences. 12: 135-138.

El-Ghaouth, A., Arul, J., Grenier, J., Benhamou, N., Asselin, A. and Belanger, R. (1994). Effect of chitosan on cucumber plants: Suppression of Pythium aphanidermatum and induction of defense reactions. Phytopathology. 84: 313-320. 
Habiba, U., Reza, S., Saha, M.L., Khan, M.R. and Hadiuzzaman, S. (2002). Endogenous bacterial contamination during in vitro culture of table banana: Identification and prevention. Plant Tissue Culture. 12: 117-124.

Hussein, N. (2012). Effects of nutrient media constituents on growth and development of banana (Musa spp.) shoot tips cultured in vitro. African Journal of Biotechnology. 11(37): 9001-9006.

Kaçar, Y.A. and Faber, B. (2012). Micropropagation of banana. Plant Cell Culture Protocols. pp. 143-151.

Muhammad, A., Rashid, H. and Hussain, I. (2007). Proliferation rate effects of BAP and kinetin on banana (Musa spp. Aaa group) 'Basrai'. Horticulture Science. 42: 1253-1255.

Nge, K. L., Nwe, N., Chandrkrachang, S. and Stevens, W.F. (2006): Chitosan as a growth stimulator in orchid tissue culture. Plant Science. 170: 1185-1190.

Ohta, K., Tanguchi, A., Konishi, N. and Hosoki, T. (1999). Chitosan treatment affects plant growth and flower quality in Eustomagrandiflorum. Hortscience. 34: 233-234.

Ortiz, R. and Vuylsteke, D. (1996). Recent advances in Musa genetics, breeding and biotechnology. Plant Breeding Abstract. 66: 1355-1363.

Pérez-Hernández, J.B. and Rosell-García, P. (2008). Inflorescence proliferation for somatic embryogenesis induction and suspension-derived plant regeneration from banana (Musa AAA, cv.'Dwarf Cavendish') male flowers. Plant Cell Reports. 27: 965-971.

Pradeep, K.P., Zachariah, G., Estellita, S. and Suma, A. (1992). Field performance of banana tissue culture plants of variety Nendran (Musa AAB). South Indian Horticulture. 40: 4.

Rabea, E.I., Badawy, M.E.T., Stevens, C.V., Smagghe, G. and Steurbaut, W. (2003). Chitosan as antimicrobial agent: applications and mode of action. Biomacromolecules. 4: 1457-1465.

Rathod, S. and Mishra, G.C. (2018). Statistical models for forecasting mango and banana yield of Karnataka, India. Journal of Agricultural Science and Technology. 20: 803-816.

Roby, D., Gadelle, A. and Toppan, A. (1987). Chitin oligosaccharides as elicitors of chitinase activity in melon plants. Biochemical and Biophysical Research Communications. 143: 885-892.

Rout, G.R., Samantaray, S. and Das, P. (2000). Biotechnology of the banana: a review of recent progress. Plant biology. 2: $512-524$.
Saravanapandeeswari, V. and Vanitha, B. (2018). Growth of area, production and productivity of banana (Musa paradisiaca) cultivation in Theni district, Tamil Nadu-An analysis by component elements. Indian Journal of Agricultural Research. 52: 107-110.

Sarma, I., Deka, A.C. and Sarma, T.C. (2021). A protocol for rapid clonal propagation and microrhizome production of Curcuma caesia Roxb. (Zingiberaceae): A critically endangerd medicinal plant of North East India. Indian Journal of Agricultural Research. 55(1): 13-22.

Sidha, M., Suprasanna, P., Bapat, V.A., Kulkarni, U.G., andShinde, B.N. (2007). Developing somatic embryogenic culture system and plant regeneration in banana. Bhabha Atomic Resource Centre (BARC) Newslett. 285: 153-161.

Sopalun, K., Thammasiri, K. and Ishikawa, K. (2010). Micropropagation of the thai orchid Grammatophyllum speciosum blume. Plant Cell, Tissue and Organ Culture. 101: 143-150.

Sultan, M.T., Khan, M.H., Hakim, M.L., Mamun, A.N.K., Morshed, M.A., Islam, M.R., and Islam, M.R. (2011): In vitro plant regeneration from male flowers of banana. International Journal of Biosciences. 1: 1-11.

Tiuterev, S., Yakubchik, M., Tarlakovsky, S., Popova, E., Vytsky, V. and Dorofeyeva, T. (1996). Chitosan: mechanism of action and ways of using as ecologically safe means in enhancement of plant disease resistance. Archives of Phytopathology and Plant Protection. 30: 323-332.

Uthairatanakij, A., Teixeira da Silva, J.A. and Obsuwan, K. (2007). Chitosan for improving orchid production and quality. Orchid Science and Biotechnology. 1: 1-5.

Vander, P., Vårum, K.M., Domard, A., El Gueddari, N.E. and Moerschbacher, B.M. (1998). Comparison of the ability of partially $\mathrm{N}$-acetylated chitosans and chitooligosaccharides to elicit resistance reactions in wheat leaves. Plant Physiology. 118: 1353-1359.

Walker-Simmons, M., Hadwiger, L. and Ryan, C.A. (1983). Chitosans and pectic polysaccharides both induce the accumulation of the antifungal phytoalexinpisatin in pea pods and antinutrient proteinase inhibitors in tomato leaves. Biochemical and biophysical research communications. 110: 194-199.

Wambugu, F.M., Njuguna, M.M., Acharya, S.S. and Mackey, M.A. (2008). Socio-economic impact of tissue culture banana (Musa spp.) in Kenya through the whole value chain approach. In IV International Symposium on Banana: International Conference on Banana and Plantain in Africa: Harnessing International. 879: 77-86. 